\title{
Chemical Composition and Nutritional Value of Three Sonchus Species
}

\author{
Galdino Xavier de Paula Filho ${ }^{1}{ }^{1}$ Tibério Fontenele Barreira, ${ }^{2}$ \\ and Helena Maria Pinheiro-Sant'Ana ${ }^{3}{ }^{3}$ \\ ${ }^{1}$ Department of Education, Federal University of Amapá, Macapá 68903-419, Brazil \\ ${ }^{2}$ Department of Plant Science, State University of North Fluminense Darcy Ribeiro, Campos dos Goytacazes 28013-602, Brazil \\ ${ }^{3}$ Department of Nutrition and Health, Federal University of Viçosa, Viçosa 36571-000, Brazil
}

Correspondence should be addressed to Galdino Xavier de Paula Filho; galdinoxavier@yahoo.com.br

Received 27 October 2021; Revised 12 February 2022; Accepted 14 February 2022; Published 3 March 2022

Academic Editor: Parise Adadi

Copyright (c) 2022 Galdino Xavier de Paula Filho et al. This is an open access article distributed under the Creative Commons Attribution License, which permits unrestricted use, distribution, and reproduction in any medium, provided the original work is properly cited.

\begin{abstract}
Species of unconventional food plants of the genus Sonchus are widely consumed in rural populations living in the Brazilian Atlantic Forest. This study investigated the nutritional composition of S. oleraceus, S. asper, and S. arvensis species. The centesimal composition was investigated according to the norms of the Association of Official Analytical Chemists, the occurrence and concentration of carotenoids and vitamins through High-Performance Liquid Chromatography, and minerals with the aid of atomic emission spectrometry in inductively coupled plasma. There was no significant difference between the water content found in the three species. However, S. asper showed higher concentrations of lipids $(1.32 \mathrm{~g} / 100 \mathrm{~g})$, carbohydrates $(0.34 \mathrm{~g} / 100 \mathrm{~g})$, total carotenoids $(5.58 \mathrm{mg} / 100 \mathrm{~g})$, and $\mathrm{Ca}(96.25 \mathrm{mg} / 100 \mathrm{~g})$, while S. arvensis had the highest concentration of vitamins E $(72.98 \mu \mathrm{g} / 100 \mathrm{~g})$ and $\mathrm{K}(604.85 \mathrm{mg} / 100 \mathrm{~g})$. S. oleraceus showed higher concentrations of Fe $(23.74 \mathrm{mg} / 100 \mathrm{~g})$. Statistically, fibers and ash presented the same proportions in S. asper and S. arvensis, as well as proteins in $S$. oleraceus and $S$. asper species. The availabilities of these vegetables together with their high nutritional value are important factors that contribute to ensuring food security for families that have these species in their diet.
\end{abstract}

\section{Introduction}

Unconventional food plants are species with spontaneous spread, receive no handling, and are found along roads, in orchards, in the middle of a pasture, and other agricultural crops. Medicinal plants have become a worldwide topic drawing an impact on world health. Herbal medicine has played a crucial role in the maintenance of the healthcare system of the wide population throughout the world. The major issue for the modern healthcare industry is to overcome pathogen resistance to antimicrobial agents and diseases caused by oxidative stress. Silver nanoparticles are also effective antiangiogenesis, anti-inflammatory, antiplatelet, and antiviral agents $[1,2]$. They are food plant species that, with the beginning of the modernization in farming, have not undergone the process of genetic improvement aiming at their technical production. Nevertheless, they are found in all biomes in Brazil, and some of them predominate in certain regions [3].

These species include leafy vegetables, fruits, rhizomes, and flowers that have historically been part of the diet of the rural population and in many cases are the only available resources for their food $[1,4]$. Some studies point to the hypothesis that these species may be nutritionally rich [5-7]. However, for many of them, there are still no studies on their nutritional composition [8].

The Atlantic Forest represents the third largest biome in Brazil in terms of territorial extension and fauna and flora biodiversity. It is also the most populous, concentrating $60 \%$ of the Brazilian population. However, it is one of the most devastated, with only $11.6 \%$ of its original vegetation cover, and the remaining percentage is protected by law $[9$, 10]. Apart from this percentage, there are the urbanized areas (cities and towns) and those used for farming activities, 
characterized by intensive cattle ranching, coffee growing (Coffea canephora L.), eucalyptus monoculture (Eucalyptus spp.), and areas of family farmers, intended for the production of annual crops, vegetable, and fruit growing [11]. In the midst of this scenario, together with other agricultural crops and forest fragments, it can be found a wide diversity of nonconventional food species highly demanded for the food consumption of the local population [2-8].

Among these species, some of the botanical genus Sonchus stand out. This species is locally known as common sow thistle (Sonchus oleraceus L.), prickly sow thistle (Sonchus asper (L.) Hill), and smooth sow thistle (Sonchus arvensis L.). These species belong to the botanical family Asteraceae. They are eaten mainly sautéed with sauces and broths [2]. From a physiological point of view, they are species of erect herbaceous size and annual cycle; their stem is hollow and little branched and also has simple, sessile leaves, with membranous blade with an auricular base and 6 to $17 \mathrm{~cm}$ long [12].

These species are originally from Europe, but they are found throughout the American continent, Africa, Asia, Australia, and New Zealand [13]. In addition to their food use, they are known for their antioxidant activity, being used in phytotherapy and their allelopathic potential used against invasive plants in agriculture $[12,14,15]$. However, in countries like Pakistan, Iran, and Russia, these species are considered weeds [16-18].

In Brazil, these species are found in native environments, especially in the South and Southeast regions of the country, being used for food and medicinal purposes [2, 12, 19]. However, some sources regard them as invasive plants in agriculture $[20,21]$. As food, these species are eaten as salads and sautéed and cooked with other foods $[2,12]$.

These species are part of the food habits of population groups in several countries, consumed in natural, or submitted to cooking. They are considered sources of dietary fiber and vitamins and strongly contribute to the food security strategies of thousands of people [22-24].

Thus, the objective of this study was to investigate the concentration of macronutrients and fibers and carotenoids, vitamins (A and $\mathrm{E}$ ), and minerals in three unconventional food species of the genus Sonchus (S. oleraceus L., S. asper (L.) Hill, and S. arvensis L.), eaten by rural populations, in samples collected in wild environments.

\section{Materials and Methods}

2.1. Sample Collection and Preparation. The species common sow thistle (S. oleraceus L.), prickly sow thistle (S. asper (L.) Hill), and smooth sow thistle (S. arvensis L.) (Figure 1) were collected in their adult stage, obtained in native environments, from spontaneously propagated plants found in the rural area of Viçosa, State of Minas Gerais (MG), Brazil (south latitude $20^{\circ} 44^{\prime}$ and west longitude $42^{\circ} 50^{\prime} 40^{\prime \prime}$ ). The species analyzed in this study were identified in herbaria in the region; they have the following identifications: S. oleraceus L., IAC 6669; S. asper (L.) Hill, IAC 6668; and S. arvensis L., RB 428940.
Sampling was carried out in five replications, composed of $500 \mathrm{~g}$ of vegetables in each replicate, and collected in five different rural communities. After collection, the samples were immediately transported to the Vitamin Analysis Laboratory of the Department of Nutrition and Health (DNS) of the Federal University of Viçosa (UFV), in plastic bags protected against light. Carotenoid analyses were performed within $36 \mathrm{~h}$ after collection, and vitamin $\mathrm{E}$ analyses were performed within $72 \mathrm{~h}$.

The species were washed under running water to remove impurities and dried with paper towels. Next, the leaves and stems showing partial or complete light-yellow color and tender texture, in addition to those attacked by insects, were removed. Later, the edible parts were homogenized in a food processor (Faet Multipratic, MC5), packed in plastic polyethylene bags covered by aluminum foil and stored at -18 $\pm 1^{\circ} \mathrm{C}$. For the analysis of macronutrients, fibers, and minerals, the samples were dehydrated in an oven with forced air circulation at $65 \pm 1^{\circ} \mathrm{C}$, for $72 \mathrm{~h}$, and stored in plastic polyethylene bags, until analysis.

2.2. Chemical Reagents and Equipment Used in the Experiment. For the extraction of carotenoids and vitamin $\mathrm{E}$, the following analytical-grade reagents were used: acetone and petroleum ether (Vetec, Brazil). The following HPLCgrade reagents were used for the analysis: acetone, hexane, isopropanol, ethyl acetate, methanol and acetonitrile (Tedia, Brazil), and glacial acetic acid (Vetec, Brazil).

The vitamin E standards $(\alpha-, \beta$-, $\gamma$-, and $\delta$-tocopherols and tocotrienols) were acquired from Calbiochem ${ }^{\otimes}$, EMD Biosciences, Inc. (USA). The $\alpha$-carotene and $\beta$-carotene patterns were isolated from concentrated carrot extract; $\beta$-cryptoxanthin and lycopene were isolated from tomato and papaya extracts, respectively, by open-column chromatography [25].

For the filtration of the samples, it was used filter paper no. JP41 J. (Prolab, Brazil), HV Millex filter units, in polyethylene with $0.45 \mu \mathrm{m}$ of porosity (Millipore, Brazil) and $3 \mathrm{ml}$ sterilized disposable syringes (TKL, China).

2.3. Chemical Analysis. The analyses of moisture, ash, proteins, lipids, and total dietary fiber were determined in three replications [26]. Moisture was determined in an oven at $65 \pm 1^{\circ} \mathrm{C}$, for $72 \mathrm{~h}$, and for ash analysis, a muffle (QUIMIS) was used at $550^{\circ} \mathrm{C}$, for $6 \mathrm{~h}$. The protein concentration was determined using the micro-Kjeldhal method, in which the crude protein was calculated by multiplying the nitrogen (N) content by 6.25 [26]. The total dietary fiber concentration was determined using the nonenzymatic gravimetric method [26].

Total carbohydrates were determined through the difference between 100 and the sum of protein fractions, lipid, moisture, fiber, and ash [27]. The total energy value (TEV) was estimated considering the conversion factors of 4,9 , and $4 \mathrm{kcal}$ per $\mathrm{g}$ for carbohydrates, lipids, and proteins, respectively [28].

For the extraction of the components of vitamin $\mathrm{E}(\alpha-$, $\beta$-, $\gamma$-, and $\delta$-tocopherols and tocotrienols), $10 \mathrm{~g}$ of the sample was weighed in a semianalytical balance, and $4 \mathrm{ml}$ of 


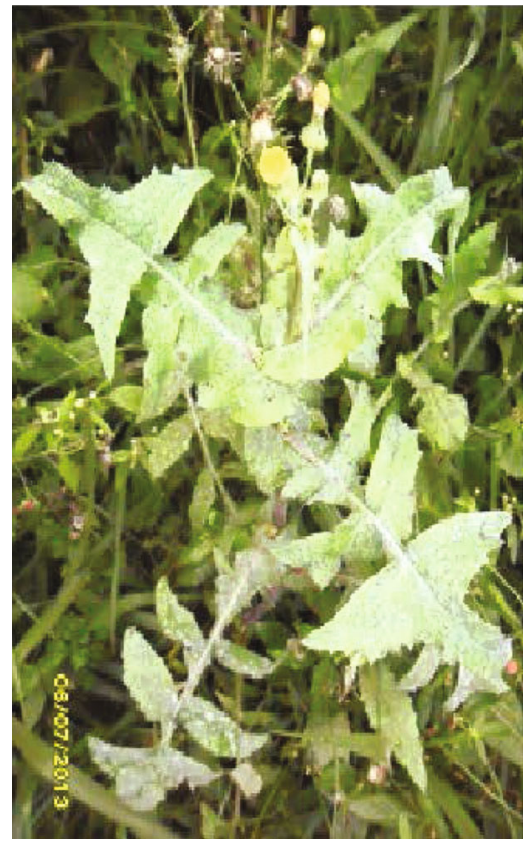

(a)

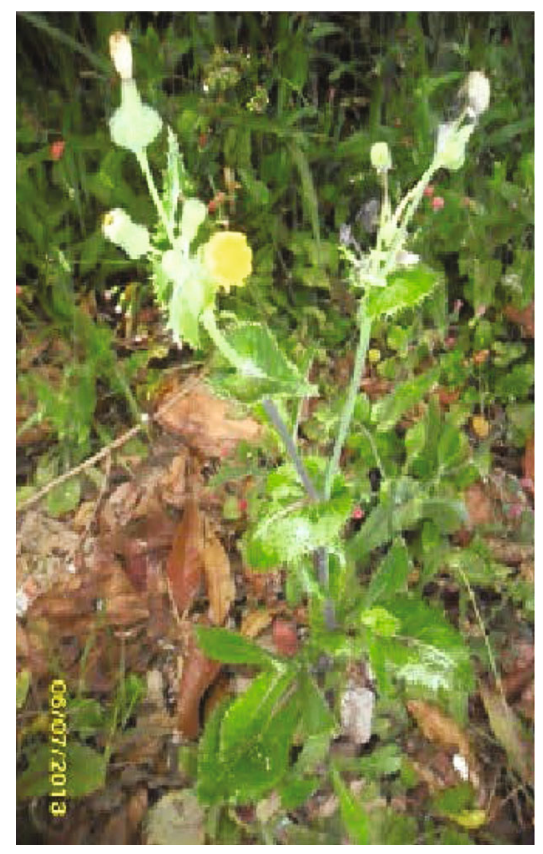

(b)

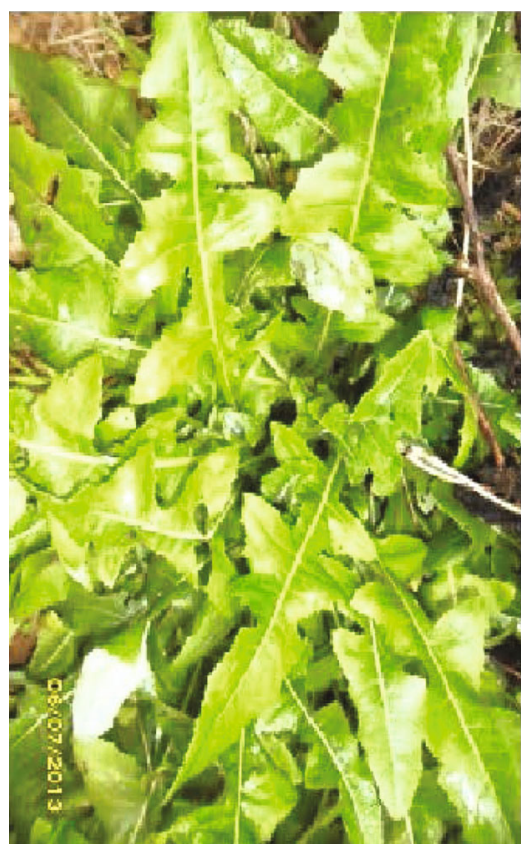

(c)

Figure 1: S. oleraceus (a), S. asper (b), and S. arvensis (c).

heated ultrapure water $\left(80 \pm 1^{\circ} \mathrm{C}\right)$ was added. After that, $10.0 \mathrm{ml}$ of isopropanol, $1.0 \mathrm{ml}$ of hexane containing $0.05 \%$ $\mathrm{BHT}$, and $5 \mathrm{~g}$ of anhydrous sodium sulfate were added. Next, $25 \mathrm{ml}$ of the extraction solvent mixture (hexane: ethyl acetate, $85: 15 v / v)$ was added. After these procedures, the sample was ground in a microgrinder at an average speed of $1 \mathrm{~min}^{-1}$. Once crushed, the samples were vacuum-filtered in a Büchner funnel using filter paper and keeping the residue in the extraction tube. The extraction step was repeated by adding $5 \mathrm{ml}$ of isopropanol and $30 \mathrm{ml}$ of the solvent mixture, with subsequent homogenization and vacuum filtration.
Then, the extract was concentrated on a rotary evaporator at $70 \pm 1^{\circ} \mathrm{C}$ for about $2 \mathrm{~min}^{-1}$ and transferred to a volumetric flask, and the volume completed to $25.0 \mathrm{ml}$ with solvent mixture. After extraction, $5.0 \mathrm{ml}$ aliquots of the vegetable extract were evaporated under nitrogen gas flow, redissolved in $2.0 \mathrm{ml}$ of HPLC grade-hexane, and filtered using filter units with $0.45 \mu \mathrm{m}$ porosity [29].

The analyses were performed in a High-Performance Liquid Chromatography system (CLAE) (Shimadzu, SCL $10 \mathrm{AD}$ VP) coupled to a fluorescence detector (RF-10A XL) $(290 \mathrm{~nm}$ excitation and $330 \mathrm{~nm}$ emission), consisting of a 
high-pressure pump with a valve for low pressure quaternary gradient (LC-10 AD VP), automatic injector with a $50 \mu \mathrm{l}$ sampling loop (SIL-10AF), and Luna column (Phenomenex, $100 \mathrm{~A}, 250 \times 4.62 \mathrm{~mm}, 5 \mu \mathrm{m})$, and equipped with a guard column (Phenomenex Si100, $4 \mathrm{~mm} \times 3 \mathrm{~mm}$ ). The mobile phase was composed of hexane:isopropanol:glacial acetic acid $(98.9: 0.6: 0.5, v / v / v)$, flow of $1.0 \mathrm{ml} \mathrm{min}^{-1}$ [29].

In the extraction of carotenoids ( $\alpha$-carotene, $\beta$-carotene, $\beta$-cryptoxanthin, and lycopene), the method proposed by Rodriguez-Amaya et al. [30] was used. Therefore, $5 \mathrm{~g}$ of each vegetable was weighed in a semianalytical balance, added with $60 \mathrm{ml}$ of cooled acetone (divided into three volumes of $20 \mathrm{ml}$ ), homogenized in a microgrinder for approximately 5 minutes, and vacuum-filtered in a Büchner funnel using filter paper. Next, the filtrate was transferred, in three fractions, to a separation funnel containing $50 \mathrm{ml}$ of cooled petroleum ether; each fraction washed three times with distilled water for a complete removal of the acetone. Anhydrous sodium sulfate was added to the petroleum ether extract to remove any water residue that might have remained and that could impair the evaporation of the material. Afterwards, the ether extract was concentrated using a rotary evaporator at a temperature of $35 \pm 1{ }^{\circ} \mathrm{C}$ and transferred to a $25.0 \mathrm{ml}$ volumetric flask, and the volume was completed with petroleum ether. For the analysis, $5.0 \mathrm{ml}$ aliquots of vegetable extracts were evaporated under nitrogen gas flow; the dry residue was redissolved in $2.0 \mathrm{ml}$ of HPLC grade-acetone. The extracts were filtered in filter units with a porosity of $0.45 \mu \mathrm{m}$, with $30 \mu \mathrm{l}$ injected into the chromatographic column for analysis.

The analyses were performed in a CLAE system (Shimadzu, SCL 10AT VP, Japão) and coupled to the diodearray detector (DAD) (Shimadzu, SPD-M10A). It was used a RP-18 column (Phenomenex, Gemini, 250 x $4.6 \mathrm{~mm}$, $5 \mu \mathrm{m}$ ) and equipped with guard column (Phenomenex, ODS, $4 \mathrm{~mm} \times 3 \mathrm{~mm}$ ); mobile phase composed of methanol: ethyl acetate: acetonitrile $(70: 20: 10 \quad v / v / v)$, flow of $2.0 \mathrm{ml} \mathrm{min}^{-1}$, was used. Chromatograms were obtained at $450 \mathrm{~nm}$ [31].

The vitamin A value was calculated considering that 1 retinol activity equivalent (RAE) corresponds to $1 \mu \mathrm{g}$ retinol, $12 \mu \mathrm{g}$ of $\beta$-carotene, and $24 \mu \mathrm{g}$ of other provitamin A carotenoids [32].

\subsection{Identification and Quantification of Carotenoids and} Vitamin E. Compounds were identified by injecting a mixture of carotenoid and vitamin E standards and then comparing the retention times obtained for the standards and for the samples analyzed under the same conditions. In addition, vitamin $\mathrm{E}$ components were identified by means of chromatography and carotenoids by comparing the absorption spectra of the patterns and peaks of interest in the samples and analyzed under the same conditions, using DAD.

For the quantification of compounds, external standardization curves were used. Appropriate dilutions of the standard solutions were performed in order to obtain concentrations comparable to the levels found in the evaluated vegetables. The construction of the analytical curves was performed by injecting, in duplicate, six increasing con- centrations of standard solutions. The quantification of the compounds in the samples was performed based on the analytical curves and regression equations obtained for the compounds identified in the samples: $\alpha$-carotene $\left(y=112.991,1393 x-1.129,0618 ; \quad R^{2}=0.999\right), \quad \beta$-carotene $\left(y=8.039 .115,2247 x-17.990,7687 ; R^{2}=0.999\right), \alpha$-tocopherol $\left(y=75.930 .901,9000 x-66.082,6598 ; \quad R^{2}=0.999\right), \quad \alpha-$ tocotrienol $\quad\left(y=29.052 .318,8274 x-106.003,6840 ; \quad R^{2}=\right.$ $0.9968), \beta$-tocopherol $(y=78.340 .650,0111 x-83.711,5802$; $\left.R^{2}=0.998\right)$, $\gamma$-tocopherol $\left(y=98.679 .794,3633 x-154.659,8232 ; R^{2}=0.997\right)$, and $\delta$ tocotrienol $\quad\left(y=142.437 .744,1691 x-246.479,6436 ; \quad R^{2}=\right.$ 0.999).

2.5. Mineral Determination. To determine the minerals $(\mathrm{Ca}$, $\mathrm{Mg}, \mathrm{Cu}, \mathrm{Mn}, \mathrm{Fe}, \mathrm{Zn}, \mathrm{Cr}, \mathrm{Na}, \mathrm{Se}, \mathrm{K}$, and $\mathrm{Mo}$ ), all glassware used was previously demineralized in a $10 \%$ nitric acid solution for 12 hours and dried in an air circulation oven [33]. Next, $1 \mathrm{~g}$ of sample and $10 \mathrm{ml}$ of nitric acid were added to the digestion tubes. Afterwards, the tubes were heated in a digester block with exhaustion at an initial temperature of $80^{\circ} \mathrm{C}$ and a progressive raise up to $160^{\circ} \mathrm{C}$, remaining at this temperature for a period of 16 hours until the formation of a clear solution. The tubes were cooled to room temperature (approximately $28^{\circ} \mathrm{C} \pm 2^{\circ} \mathrm{C}$ ), and the contents were transferred to volumetric flasks and completed up to $50 \mathrm{ml}$ with deionized water. The tubes were washed with deionized water and vortexed, and their contents were poured into volumetric flasks, until the volume was completed [33]. The obtained solution was used to read the concentration of minerals through inductively coupled plasma atomic emission spectrometry (ICP-AES) (Perkin Elmer, Optima 8300).

2.6. Data Analysis. A completely randomized design was used with three treatments represented by each food species of the genus Sonchus (S. oleraceus, S. asper, and S. arvensis), five replicates for vitamin $\mathrm{E}$ and carotenoids, three replicates for proximate composition, and three replicates in duplicates for minerals. The data were stored in spreadsheets using the Microsoft Office Excel program, version 2007. To verify the existence of differences between the nutritional value of vegetables, the data were subjected to analysis of variance. To compare the means of the treatments that showed differences, the Duncan test was used, at $5 \%$ level of probability. The statistical analysis was performed using the SAS software, version 9.2 (2008), licensed to UFV.

\section{Results and Discussion}

3.1. Macronutrients and Caloric Density. The species analyzed in this study were collected in a wild environment, and because they are spontaneous plants, they may show high genetic variability [34]. According to Kinupp and Barros [35], little information about the nutritional composition of native food plants in Brazil is available, and when available, most are studies carried out in other countries for widely distributed species, but under very different edaphoclimatic conditions. In addition, it is highlighted that the composition of nutrients in food is influenced by inherent 
TABLE 1: Mean values of macronutrients and caloric density in Sonchus species.

\begin{tabular}{lcrr}
\hline Variables & S. oleraceus & S. asper & S. arvensis \\
\hline Moisture (g/100 g) & $91.83 \pm 0.25^{\mathrm{a}}$ & $91.77 \pm 0.76^{\mathrm{a}}$ & $92.31 \pm 0.66^{\mathrm{a}}$ \\
Total dietary fiber (g/100 g) & $3.97 \pm 0.05^{\mathrm{b}}$ & $4.38 \pm 0.34^{\mathrm{a}}$ & $4.30 \pm 0.02^{\mathrm{a}}$ \\
Ash (g/100 g) & $1.06 \pm 0.02^{\mathrm{b}}$ & $1.12 \pm 0.01^{\mathrm{a}}$ & $1.16 \pm 0.02^{\mathrm{a}}$ \\
Lipids (g/100 g) & $1.12 \pm 0.01^{\mathrm{b}}$ & $1.32 \pm 0.08^{\mathrm{a}}$ & $1.06 \pm 0.05^{\mathrm{b}}$ \\
Carbohydrates (g/100 g) & $0.17 \pm 0.04^{\mathrm{b}}$ & $0.34 \pm 0.07^{\mathrm{a}}$ & $0.12 \pm 0.03^{\mathrm{b}}$ \\
Proteins (g/100 g) & $1.88 \pm 0.01^{\mathrm{a}}$ & $1.97 \pm 0.02^{\mathrm{a}}$ & $1.55 \pm 0.02^{\mathrm{b}}$ \\
Caloric density (kcal/100 g) & $18.31 \pm 0.25^{\mathrm{b}}$ & $21.13 \pm 0.91^{\mathrm{a}}$ & $16.29 \pm 0.62^{\mathrm{c}}$ \\
\hline
\end{tabular}

Values expressed in dry matter; mean of 3 replicates; data shown in mean \pm standard deviation. Means followed by the same letter on the line do not differ by the test of Duncan at the $5 \%$ level of significance.

TABLE 2: Concentrations of carotenoids and vitamins in Sonchus species.

\begin{tabular}{lccc}
\hline Compounds & S. oleraceus & S. asper & S. arvensis \\
\hline Total vitamin A (RAE/100 g) & $427.61 \pm 57.03^{\mathrm{a}}$ & $455.89 \pm 39.28^{\mathrm{a}}$ & $369.83 \pm 2.84^{\mathrm{b}}$ \\
Total carotenoids (mg/100 g) & $5.28 \pm 0.68^{\mathrm{b}}(100 \%)$ & $5.58 \pm 0.48^{\mathrm{a}}(100 \%)$ & $4.59 \pm 0.03^{\mathrm{c}}(100 \%)$ \\
$\alpha$-Carotene & $0.30 \pm 0.02^{\mathrm{a}}(5.69 \%)$ & $0.22 \pm 0.03^{\mathrm{b}}(3.90 \%)$ & $0.34 \pm 0.05^{\mathrm{a}}(7.26 \%)$ \\
$\beta$-Carotene & $4.97 \pm 0.78^{\mathrm{b}}(94.31 \%)$ & $5.42 \pm 0.46^{\mathrm{a}}(96.09 \%)$ & $4.34 \pm 0.07^{\mathrm{a}}(92.74 \%)$ \\
Total vitamin E $(\mu \mathrm{g} / 100 \mathrm{~g})$ & $40.37 \pm 3.79^{\mathrm{c}}(100 \%)$ & $49.62 \pm 7.25^{\mathrm{b}}(100 \%)$ & $72.98 \pm 2.91^{\mathrm{a}}(100 \%)$ \\
$\alpha$-Tocopherol & $20.84 \pm 0.94^{\mathrm{b}}(51.63 \%)$ & $17.02 \pm 1.59^{\mathrm{b}}(34.30 \%)$ & $52.36 \pm 0.40^{\mathrm{a}}(71.75 \%)$ \\
$\alpha$-Tocotrienol & $13.53 \pm 2.53^{\mathrm{b}}(33.51 \%)$ & $21.58 \pm 4.51^{\mathrm{a}}(43.49 \%)$ & $11.26 \pm 1.21^{\mathrm{b}}(15.43 \%)$ \\
$\beta$-Tocopherol & nd & $4.04 \pm 0.08^{\mathrm{a}}(8.14 \%)$ & $3.75 \pm 0.11^{\mathrm{b}}(5.14 \%)$ \\
$\gamma$-Tocopherol & $6.00 \pm 0.32^{\mathrm{b}}(14.86 \%)$ & $6.98 \pm 1.07^{\mathrm{a}}(14.07 \%)$ & $5.61 \pm 1.19^{\mathrm{c}}(7.68 \%)$ \\
\hline
\end{tabular}

Values expressed in fresh matter; mean of 5 replicates; data shown in mean \pm standard deviation. Means followed by the same letter on the line do not differ by the test of Duncan at the $5 \%$ level of significance.

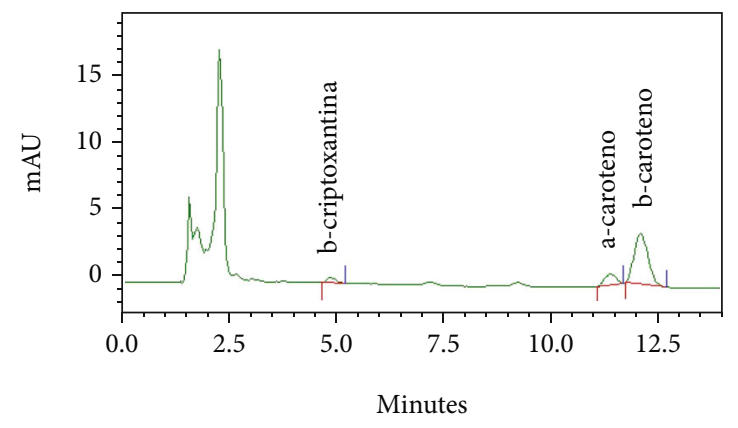

(a)

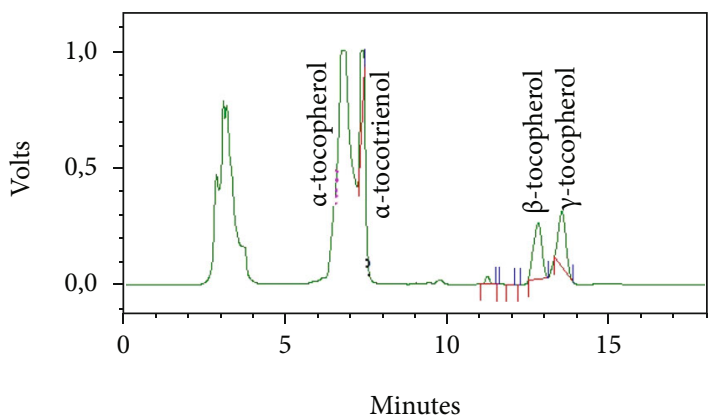

(b)

FIgURE 2: Chromatographic profile of carotenoids (a) and vitamin E (b) in S. arvensis.

(age, maturity, species, variety, and form of cultivation) and environmental (climate, soil type, rainfall, and season) factors, period, and conditions of storage and handling (preparation and processing methods) [35]. Thus, comparison with other studies is rather difficult, and in the same study, considering the same species, there may be greater variability of the data between the replicates used.

Regarding the items analyzed in Table 1, the literature has few similar studies on these species, which makes it very difficult to compare them with other studies. However, it is worth mentioning that the species $S$. oleraceus is included in the Brazilian Table of Food Composition [36], with results of moisture $(90.2 \mathrm{~g} / 100 \mathrm{~g})$, total dietary fiber $(3.5 \mathrm{~g} / 100 \mathrm{~g})$, and ash $(1.4 \mathrm{~g} / 100 \mathrm{~g})$, which are similar to those found in this study. This species was also analyzed by Agea et al. [37], with samples collected in Uganda and a methodology similar to this study, with results for moisture $(86.32 \mathrm{~g} / 100 \mathrm{~g})$ and total dietary fiber $(3.57 \mathrm{~g} / 100 \mathrm{~g})$, similar to those found here. The concentrations of macronutrients, fibers, and caloric value of the species $S$. asper and $S$. oleraceus were investigated by Guil-Guerrero et al. [38] in a study carried out in Spain. These authors found some values close to those of this study, as well as moisture $(87.2 \mathrm{~g} / 100 \mathrm{~g})$, lipids $(0.8 \mathrm{~g} / 100 \mathrm{~g})$, and total dietary fiber $(35.6 \mathrm{~g} / 100 \mathrm{~g})$ in $S$. oleraceus and moisture $(86.4 \mathrm{~g} / 100 \mathrm{~g})$ and total dietary fiber $(32.5 \mathrm{~g} / 100 \mathrm{~g})$ in $S$. asper.

Regarding the statistical differences observed in the means of the treatment, only the moisture concentration did not differ. At the same time, caloric density was the only 
Table 3: Mineral concentrations in Sonchus species.

\begin{tabular}{lccc}
\hline $\begin{array}{l}\text { Minerals (mg/ } \\
100 \mathrm{~g})\end{array}$ & S. oleraceus & S. asper & S. arvensis \\
\hline $\mathrm{K}$ & $490.09 \pm 46.36$ & $\begin{array}{c}519.34 \pm 23.5 \\
\mathrm{c}\end{array}$ & $604.85 \pm 59.95$ \\
$\mathrm{a}$ & $83.26 \pm 7.16^{\mathrm{b}}$ & $96.25 \pm 6.92^{\mathrm{a}}$ & $81.91 \pm 10.28^{\mathrm{b}}$ \\
$\mathrm{Ca}$ & $30.57 \pm 2.71^{\mathrm{c}}$ & $33.34 \pm 3.63^{\mathrm{b}}$ & $38.06 \pm 1.51^{\mathrm{a}}$ \\
$\mathrm{Mg}$ & $0.13 \pm 0.02^{\mathrm{a}}$ & $0.14 \pm 0.01^{\mathrm{a}}$ & $0.12 \pm 0.03^{\mathrm{a}}$ \\
$\mathrm{Cu}$ & $0.77 \pm 0.04^{\mathrm{a}}$ & $0.83 \pm 0.06^{\mathrm{a}}$ & $0.59 \pm 0.05^{\mathrm{b}}$ \\
$\mathrm{Mn}$ & $23.74 \pm 0.8^{\mathrm{a}}$ & $7.77 \pm 2.07^{\mathrm{b}}$ & $3.43 \pm 1.31^{\mathrm{c}}$ \\
$\mathrm{Fe}$ & $0.27 \pm 0.02^{\mathrm{b}}$ & $0.43 \pm 0.05^{\mathrm{a}}$ & $0.26 \pm 0.04^{\mathrm{b}}$ \\
$\mathrm{Zn}$ & $\mathrm{nd}$ & $0.01 \pm 0.01^{\mathrm{a}}$ & $0.02 \pm 0.00^{\mathrm{a}}$ \\
$\mathrm{Cr}$ & $5.62 \pm 2.19^{\mathrm{a}}$ & $4.81 \pm 0.42^{\mathrm{b}}$ & $4.06 \pm 0.30^{\mathrm{b}}$ \\
$\mathrm{Na}$ & $0.04 \pm 0.01^{\mathrm{a}}$ & $0.03 \pm 0.01^{\mathrm{a}}$ & $0.04 \pm 0.01^{\mathrm{a}}$ \\
$\mathrm{Se}$ &
\end{tabular}

Values expressed in dry matter; mean of 3 replicates; data shown in mean \pm standard deviation. Means followed by the same letter on the line do not differ by the test of Duncan at the $5 \%$ level of significance.

parameter that differed statistically in the three analyzed species. As for the other nutrients, at least in two species, there was statistical similarity, which may be related to the botanical aspect as the species belonged to the same genus, and also to the physiology of the species, verified in the physical similarity between them (Figure 1) and also shown by Khan et al. [39] and Liu et al. [40]. In the cases in which they differed, although these differences are not excessively accentuated, however, they may be associated with the fact that the samples were obtained from wild species, which have high genetic variability, and the conditions under which they developed were not subjected to control of environmental factors [34, 41].

In the few studies found on the concentration of macronutrients, fibers, and caloric value in these species, it is observed that the concentrations of moisture and dietary fibers tend to approximate, while the other items (ashes, lipids, carbohydrates, and proteins) tend to present greater variability. Although it is not the objective of this study, it is assumed that these differences may be related to several factors (technical, environmental, temporal) [37, 38, 42], since the experiments were carried out in places with different environmental characteristics and different times and in some cases with different extraction and methods of analysis.

3.2. Carotenoids and Vitamins. In relation to the concentration of carotenoids and vitamins in wild vegetables, besides the environmental factors interfering in their composition, the ways in which samples are obtained from the collection point to the place of processing can also interfere in the concentration of these nutrients [43]. Thus, standardization of the methodology was carefully observed as it can be seen in the methodology described.

According to the results shown in Table 2 and Figure 2, a small variability was observed between the results found for the three species. The concentrations of total carotenoids and vitamin A showed low standard deviations among the replicated. For total vitamin E, the three species differed $(\alpha<0.05)$ in terms of concentration, in which S. arvensis showed the highest concentration, due to the higher concentration of $\alpha$-tocopherol in this species.

The vitamin A values found for S. oleraceus in this study proved to be significant and are lower than those available in the Brazilian Table of Food Composition for this species (567 RAE/100 g) [36]. The concentration of $\beta$-carotene in S. oleraceus is also lower when compared to that found by Agea et al. [37] $(13.4 \mathrm{mg} / 100 \mathrm{~g})$, which is around three times higher than that observed in this study.

In our experiment, the results were inferior to those found by Guil-Guerrero et al. [38] in which S. asper showed $8 \mathrm{mg} / 100 \mathrm{~g}$, while $S$. oleraceus showed a concentration around three times as higher when compared with the present study $(15.8 \mathrm{mg} / 100 \mathrm{~g})$.

Regarding the content of vitamin E, the results found in the present study were below those found in S. asper ( $49 \mu \mathrm{g} /$ $100 \mathrm{~g})$ by Oliveira [44]. The $\alpha$-tocopherol content was also higher in S. oleraceus $(197 \mu \mathrm{g} / 100 \mathrm{~g})$ and S. asper $(205 \mu \mathrm{g} /$ $100 \mathrm{~g}$ ); although in this study, these compounds were analyzed in dry matter. The place of collection, as well as the ways in which these species are obtained, can influence the content of vitamins and minerals in vegetables, which may explain this variation between the present study and the comparative literature.

It is worth mentioning that the results found for carotenoids and vitamin E, in addition to being significant, are important from a nutritional point of view, since there are studies that prove nutritional deficiency of these compounds in the study region, so that these species can be included in food diets for children and lactating women $[45,46]$.

3.3. Minerals. The studied minerals were found in the three species investigated in this work (Table 3). However, the concentration of minerals in the foods is not a safe indicator of the nutritional value of the amounts absorbed and subsequently used by the body, since some minerals such as calcium, iron, zinc, copper, and magnesium can form insoluble complexes with antinutritional factors (phytate, oxalate) normally found in vegetables, thus decreasing their bioavailability [47].

The results found in the concentration of minerals in $S$. oleraceus are in accordance with some minerals available in the Brazilian Food Composition Table, which in turn is based on the Food Recommendations Guide of the World Health Organization (WHO), such as $\mathrm{Mg}(30 \mathrm{mg} / 100 \mathrm{~g})$ and $\mathrm{Cu}(0.20 \mathrm{mg} / 100 \mathrm{~g})$ [36]. Guil-Guerrero et al. [38] found $K$ values for $S$. asper equal to $583.9 \mathrm{mg} / 100 \mathrm{~g}$ and $\mathrm{Fe}$ for $S$. oleraceus equal to $37.8 \mathrm{mg} / 100 \mathrm{~g}$, both relatively close to those found in this study. On the other hand, in a few other studies found on the concentration of minerals in these species, there is a considerable disparity between some results. For example, the concentrations of $\mathrm{Mg}$ in $S$. asper and in $S$. oleraceus $(0.69 \mathrm{mg} / 100 \mathrm{~g}$ and $0.61 \mathrm{mg} / 100 \mathrm{~g}$, respectively), found by Jimoh et al. [48], are around 50 times as lower than those found in the present study. This difference may be related to the precision with which these values are expressed, in small units ( $\mathrm{mg}$ and $\mu \mathrm{g}$ ). In addition, any sampling error may result in a final variable of greater 
amplitude. Another possibility may be related to the fertility of the soils where these plants grow, and in turn, to the place where the samples are collected, since the underground characteristics directly influence the acquisition of nutrients by the plants [49].

$S$. arvensis was the species that showed the highest concentration of $K$, while $S$. asper was the richest in Ca, and $S$. oleraceus showed the highest concentration of $\mathrm{Fe}(\alpha<0.05$ ). Among the species analyzed in the present study, S. arvensis is the least studied as to its nutritional composition, although it occurs in several regions of the world besides being for food and herbal purposes $[14,50]$. However, studies on its nutritional components are scarce, which values and highlights the novelty of the results found in the present study.

\section{Conclusions}

The species studied here showed an important concentration of dietary fibers and low caloric density, which is a good indicator of nutritional quality, considering that the higher the caloric density of the food ingested, the greater the risk to develop obesity, cardiovascular diseases, and so on.

The three species of the Sonchus genus showed carotenoids and vitamin E, where the species S. arvensis stood out, being the richest in vitamin $\mathrm{E}$.

The minerals ( $\mathrm{K}, \mathrm{Ca}, \mathrm{Mg}, \mathrm{Cu}, \mathrm{Mn}, \mathrm{Fe}, \mathrm{Zn}, \mathrm{Na}$, and $\mathrm{Se}$ ) were found in the three species in the study. S. arvensis was the species with the highest content of potassium, while $S$. asper was the richest in calcium and S. oleraceus the richest in iron. Thus, the potential that these species represent for food and nutritional security strategies is emphasized, due to their wide availability in wild environments, which can be obtained with no financial costs, due to the sanity that they present as pesticides in their production systems and because they are part of the eating habits of many families and rural populations living in these regions.

\section{Data Availability}

Data used for this research and analysis is available from the corresponding author and will be provided upon reasonable request.

\section{Disclosure}

I declare that the funding body had no role in the design of the study; the collection, analysis, and interpretation of the data; the writing of this manuscript; and the decision to submit it for publication.

\section{Conflicts of Interest}

The authors declare no conflict of interest.

\section{Authors' Contributions}

H.M.P.-S. contributed to the conceptualization and supervision. G.X.d.P.F. and T.F.B. contributed to the methodology and writing-review and editing.

\section{Acknowledgments}

The authors would like to thank the Graduate Program in Agroecology at the Federal University of Viçosa, Minas Gerais, Brazil, for the possibility of carrying out this study; to the National Council for Scientific and Technological Development $(\mathrm{CNPq})$ for the scientific initiation scholarship; to Minas Gerais State Research Support Foundation (FAPEMIG) and to Arthur Bernardes Foundation (FUNARBE) for the financial support for the purchase of chemical reagents and laboratory material; and to the Coordination of Support for Higher Education Personnel (CAPES) for the master's scholarship. This study was funded by the National Council for Scientific and Technological Development $(\mathrm{CNPq})$, the Minas Gerais State Research Support Foundation (FAPEMIG), the Arthur Bernardes Foundation (FUNARBE), and the Coordination of Support for Higher Education Personnel (CAPES).

\section{References}

[1] R. Ullah, A. S. Alqahtani, O. M. Noman, A. M. Alqahtani, S. Ibenmoussa, and M. Bourhia, "A review on ethnomedicinal plants used in traditional medicine in the Kingdom of Saudi Arabia," Saudi Journal of Biological Sciences, vol. 27, no. 10, pp. 2706-2718, 2020.

[2] N. Ahmad, Fozia, M. Jabeen et al., "Green fabrication of silver nanoparticles using Euphorbia serpens Kunth aqueous extract, their characterization, and investigation of its in vitro antioxidative, antimicrobial, insecticidal, and cytotoxic activities," Biomed Research International; vol, vol. 2022, pp. 1-11, 2022.

[3] M. L. Leal, R. P. Alves, and N. Hanazaki, "Knowledge, use, and disuse of unconventional food plants," Journal of Ethnobiology and Ethnomedicine, vol. 14, no. 1, pp. 6-9, 2018.

[4] A. K. Mahapatra, S. Mishra, U. C. Basak, and C. P. Panda, "Nutrient analysis of some selected wild edible fruits of deciduous forests of India: an explorative study towards non conventional bio-nutrition," Advance Journal of Food Science and Technology, vol. 2012, no. 4, pp. 15-21, 2012.

[5] M. C. Sánchez-Mata, R. D. C. Loera, P. Morales et al., "Wild vegetables of the Mediterranean area as valuable sources of bioactive compounds," Genetic Resources and Crop Evolution, vol. 59, no. 3, pp. 431-443, 2012.

[6] C. Termote, M. B. Meyi, B. D. Djailo et al., "A biodiverse rich environment does not contribute to a better diet: a case study from DR Congo," PLoS One, vol. 7, no. 1, pp. 1-10, 2012.

[7] M. M. A. Satter, M. M. R. L. Khan, S. A. Jabin, N. Abedin, M. F. Islam, and B. Shasha, "Nutritional quality and safety aspects of wild vegetables consume in Bangladesh," Asian Pacific Journal of Tropical Biomedicine, vol. 6, no. 2, pp. 125-131, 2016.

[8] G. X. Paula Filho, T. F. Barreira, S. S. Pinheiro, L. M. Cardoso, H. S. D. Martino, and H. M. Pinheiro-Sat'Ana, "Melão croá" (Sicana sphaericaVell.) and 'maracujina' (Sicana odoriferaNaud.): chemical composition, carotenoids, vitamins and minerals in native fruits from the Brazilian Atlantic forest," Fruits, vol. 70, no. 6, pp. 341-349, 2015.

[9] F. R. Scarano and P. Ceotto, "Brazilian Atlantic forest: impact, vulnerability, and adaptation to climate change," Biodiversity and Conservation, vol. 24, no. 9, pp. 2319-2331, 2015.

[10] V. G. Ferro, P. Lemes, A. S. Melo, and R. Loyola, "The reduced effectiveness of protected areas under climate change threatens 
Atlantic Forest tiger moths," PLoS One, vol. 9, no. 9, pp. 1-12, 2014.

[11] A. G. O. P. Barreto, G. Berndes, G. Spavorek, and S. Wirsenius, "Agricultural intensification in Brazil and its effects on landuse patterns: an analysis of the 1975-2006 period," Global Change Biology, vol. 2013, p. 19, 2013.

[12] V. F. Kinupp and H. Lorenzi, Plantas Alimentícias Não Convencionais (PANC) no Brasil: Guia de Identificação, Aspectos Nutricionais e Receitas Ilustradas, Instituto Plantarum de Estudos da Flora, São Paulo, Brazil, 1st edition, 2014.

[13] N. H. Gomaa, M. O. Hassan, G. M. Fahmy, L. González, O. Hammouda, and A. M. Atteya, "Allelopathic effects of Sonchus oleraceus L. on the germination and seedling growth of crop and weed species," Acta Botanica Brasilica, vol. 28, pp. 408-416, 2014.

[14] R. A. Khan, R. M. Khan, S. Sahreen, and M. Ahmed, "Evaluation of phenolic contents and antioxidant activity of various solvent extracts of Sonchus asper (L.) Hill," Chemistry Central Journal, vol. 6, no. 1, pp. 1-7, 2012.

[15] Z. Q. Ou, D. M. Schmierer, T. Rades, L. Larsen, and A. McDowell, "Application of an online post-column derivatization HPLC-DPPH assay to detect compounds responsible for antioxidant activity in Sonchus oleraceus L. leaf extracts," The Journal of Pharmacy and Pharmacology, vol. 65, no. 2, pp. 271-279, 2013.

[16] M. Tauseef, F. Ihsan, W. Nazir, and J. Farooq, "Weed flora and importance value index (IVI) of the weeds in cotton crop fields in the region of Khanewal," Pakistan Journal of Weed Science Research, vol. 18, pp. 319-330, 2012.

[17] K. Jamshidi, A. R. Yousefi, and M. Oveisi, "Effect of cowpea (Vigna unguiculata) intercropping on weed biomass and maize (Zea mays) yield," New Zealand Journal of Crop and Horticultural Science, vol. 41, no. 4, pp. 180-188, 2013.

[18] J. Yu and D. W. Morishita, "Response of seven weed species to corn gluten meal and white mustard (Sinapis alba) seed meal rates," Weed Technology, vol. 28, pp. 259-265, 2014.

[19] F. Leitão, S. G. Leitão, V. S. Fonseca-Kruel, I. M. Silva, and K. Martins, "Medicinal plants traded in the open-air markets in the state of Rio de Janeiro, Brazil: an overview on their botanical diversity and toxicological potential," Revista Brasileira de Farmacognosia, vol. 24, no. 2, pp. 225-247, 2014.

[20] A. M. Massenssini, V. H. A. Bonduki, M. R. Tótoloa, F. A. Ferreira, and M. D. Costa, "Arbuscular mycorrhizal associations and occurrence of dark septate endophytes in the roots of Brazilian weed plants," Mycorrhiza, vol. 24, no. 2, pp. 153-159, 2014.

[21] H. R. Medeiros, A. T. Hoshino, M. C. Ribeiro, and A. O. Menezes Junior, "Landscape complexity affects cover and species richness of weeds in Brazilian agricultural environments," Basic and Applied Ecology, vol. 17, no. 8, pp. 731-740, 2016.

[22] A. Fratianni, A. D’Agostino, S. Niro, A. Bufano, B. Paura, and G. Panfili, "Loss or gain of lipophilic bioactive compounds in vegetables after domestic cooking? Effect of steaming and boiling," Effect of Steaming and Boiling. Foods, vol. 10, no. 5, p. $960,2021$.

[23] G. Panfili, S. Niro, A. Bufano et al., "Bioactive compounds in wild Asteraceae edible plants consumed in the Mediterranean diet," Plant Foods for Human Nutrition, vol. 75, no. 4, pp. 540546, 2020.

[24] S. A. Petropoulos, A. Fernandes, N. Tzortzakis et al., "Bioactive compounds content and antimicrobial activities of wild edible
Asteraceae species of the Mediterranean flora under commercial cultivation conditions," Food Research International, vol. 119, pp. 859-868, 2019.

[25] D. B. Rodriguez-Amaya, "Critical review of provitamin A determination in plant foods," Journal of Micronutrient Analysis, vol. 5, pp. 191-225, 1989.

[26] AOAC, Official Methods of Analysis of the Association of Official Analytical Chemists. AOAC, Association of Official Analytical Chemists (AOAC, Washington, D.C, EUA, 2010.

[27] IBGE, Tabelas de Composição de Alimentos. IBGE, Instituto Brasileiro de Geografia e Estatística (IBGE). Estudo Nacional da Despesa Familiar - ENDEF, Rio de Janeiro, Brazil, 1998.

[28] C. D. Frary and R. K. Johnson, Alimentos, Nutrição e Dietoterapia, Energia. In: Mahan, L.K.; Escott-Stump, S, Rocca: São Paulo, Brazil, 2005.

[29] H. M. Pinheiro-Sant'Ana, M. Guinazi, D. S. Oliveira, C. M. Della-Lucia, B. L. Reis, and S. C. C. Brandão, "Method for simultaneous analysis of eight vitamin $\mathrm{E}$ isomers in various foods by high performance liquid chromatography and fluorescence detection," Journal of Chromatography. A, vol. 1218, no. 47, pp. 8496-8502, 2011.

[30] D. B. Rodriguez-Amaya, L. C. Raymundo, T. Lee, K. L. Simpson, and C. O. Chichester, "Carotenoid pigment changes in ripening Momordica charantia fruits," Annals of Botany, vol. 167, pp. 615-624, 1976.

[31] H. M. Pinheiro-Sant'Ana, P. C. Stringheta, S. C. C. Brandão, and R. M. C. Azeredo, "Carotenoid retention and vitamin A value in carrot (Daucus carota L.) prepared by food service," Food Chemistry, vol. 61, pp. 145-151, 1998.

[32] IOM, Dietary Reference Intakes (DRIs): Vitamin a, Vitamin k, Arsenic, Boron, Cromium, Copper, Iodine, Iron, Manganese, Molybdenium, Nickel, Silicon, Vanadium and Zinc. IOM, Institute of Medicine (IOM), Washington, EUA, 2011.

[33] J. C. Gomes and G. F. Oliveira, "Fotometria de chama e espectrofotometria de absorção atômica," Análises físico-químicas de alimentos, vol. 4, pp. 47-52, 2011.

[34] M. El-Soda, M. Malosetti, B. J. Zwaan, M. Koornneef, and M. G. M. Aarts, "Genotype $\times$ environment interaction QTL mapping in plants: lessons from Arabidopsis," Trends in Plant Science, vol. 19, no. 6, pp. 390-398, 2014.

[35] V. F. Kinupp and I. B. I. Barros, “Teores de proteína e minerais de espécies nativas, potenciais hortaliças e frutas," Food Science and Technology, vol. 28, no. 4, pp. 846-857, 2008.

[36] UNICAMP, Tabela Brasileira de Composição de Alimentos: TACO, Universidade Estadual de Campinas (UNICAMP), Campinas, Brazil, 4th edition, 2011.

[37] J. G. Agea, J. M. Kimondo, D. A. Woiso et al., "Proximate composition, vitamin $\mathrm{C}$ and beta-carotene contents of fifteen selected leafy wild and semi-wild food plants (WSWFPs)," Journal National Product Plant Resources, vol. 4, pp. 1-12, 2014.

[38] J. L. Guil-Guerrero, A. Giménez-Giménez, I. Rodríguez-García, and M. E. Torija-Isasa, "Nutritional composition of Sonchus species (S. asper L., S. oleraceus L. and S. tenerrimus L.)," Journal of the Science of Food and Agriculture, vol. 76, no. 4, pp. 628-632, 1998.

[39] K. Y. Khan, M. A. Khan, R. Niamat et al., "Element content analysis of plants of genus Ficus using atomic absorption spectrometer," African Journal Pharmacy and Pharmacology, vol. 5, no. 3, pp. 317-321, 2011.

[40] C. Liu, Y. Liu, K. Guo, S. Wang, and Y. Yang, "Concentrations and resorption patterns of 13 nutrients in different plant 
functional types in the karst region of South-Western China," Annals of Botany, vol. 113, no. 5, pp. 873-885, 2014.

[41] P. J. Flood, J. Harbinson, and M. G. M. Aarts, "Natural genetic variation in plant photosynthesis," Trends in Plant Science, vol. 16, no. 6, pp. 327-335, 2011.

[42] X. Li and P. Yang, "Research progress of Sonchus species," International Journal of Food Properties, vol. 21, no. 1, pp. 147-157, 2018.

[43] L. Zhan, J. Hu, Y. Li, and L. Pang, "Combination of light exposure and low temperature in preserving quality and extending shelf-life of fresh-cut broccoli (Brassica oleracea L.)," Postharvest Biology and Technology, vol. 72, pp. 76-81, 2012.

[44] H. A. B. Oliveira, P. C. Anunciação, B. P. Silva et al., "Nutritional value of non-conventional vegetables prepared by family farmers in rural communities," Ciência Rural, vol. 49, no. 8, pp. 1-10, 2019.

[45] M. B. M. C. Lisboa, E. O. Oliveira, J. A. Lamounier, C. A. M. Silva, and R. N. Freitas, "Prevalence of iron-deficiency anemia in children aged less than 60 months: a population-based study from the state of Minas Gerais, Brazil," Revista de Nutrição, vol. 28, no. 2, pp. 121-131, 2015.

[46] M. R. Machado, F. Kamp, J. C. Nunes, T. El-Bacha, and A. G. Torres, "Breast milk content of vitamin A and E from early- to mid-lactation is affected by inadequate dietary intake in Brazilian adult women," Nutrients, vol. 11, no. 9, p. 11, 2019.

[47] A. A. Hailu and G. Addis, "The content and bioavailability of mineral nutrients of selected wild and traditional edible plants as affected by household preparation methods practiced by local community in Benishangul Gumuz Regional State, Ethiopia," Ethiopia. International J Food Science, vol. 2016, pp. 17, 2016.

[48] F. O. Jimoh, A. A. Adedapo, and A. J. Afolayan, "Comparison of the nutritive value, antioxidant and antibacterial activities of Sonchus asper and Sonchus oleraceus," Record of National Product, vol. 5, pp. 29-42, 2011.

[49] G. Zemunik, B. L. Turner, H. Lambers, and E. Laliberté, "Diversity of plant nutrient-acquisition strategies increases during long-term ecosystem development," Nature plants, vol. 1, no. 5, p. 15050, 2015.

[50] S. Hussain, F. Ullah, M. Ayaz et al., "In silico, cytotoxic and antioxidant potential of novel ester, 3-hydroxyoctyl -5- transdocosenoate isolated from Anchusa arvensis (L.) M.Bieb. against cancer cells," Drug Design, Development and Therapy, vol. 13, pp. 4195-4205, 2019. 